\title{
Characterization of Particle Size Distributions of Powdery Building Material Aerosol Generated by Fluidization and Gravitation
}

\author{
Tadas Prasauskas, Aida Žemaitytė, Edvinas Krugly, Darius Čiužas and \\ Dainius Martuzevičius \\ Department of Environmental Engineering, Kaunas University of Technology, Lithuania
}

cross ${ }^{\text {ref }}$ http://dx.doi.org/10.5755/j01.erem.61.3.1519

(received in April, 2012, accepted in September, 2012)

\begin{abstract}
This study aims to identify particle size distributions (PSD) of aerosol of powdery building materials commonly used in construction work (cement, chalk, clay, wood sawdust, wood grinding dust, gypsum, hydrated lime, masonry grout, quartz sand, sand and structural lime) by two aerosolization methods: fluidization and gravitation. Fluidization and gravitation methods represent industrial activities such as pneumo-transportation and unloading. Both particle resuspension mechanisms have been modelled in laboratory conditions.

The particle size distributions of resuspended particulate matter from powdery building materials were rather similar identified by both fluidization and gravitation methods, with an exception of wood sawdust and sand. The $\mathrm{PM}_{10}$ fraction ranged between $30 \%$ and $87 \%, \mathrm{PM}_{2.5}$ from $7 \%$ to $28 \%$ and $\mathrm{PM}_{1.0}$ from $3 \%$ to $7 \%$ of the total mass of particulate matter. The highest $\mathrm{PM}_{10} / \mathrm{PM}_{\text {total }}$ ratio was calculated for masonry grout -0.87 , and the lowest ratio for quartz sand - 0.30. The highest ratio of $\mathrm{PM}_{2.5} / \mathrm{PM}_{\text {total }}$ was calculated for sand -0.23 , the lowest for quartz sand - 0.07. Substantial quantities of $\mathrm{PM}_{2.5}$ were found to be emitted implying a potential threat to human health.

Key words: air pollution, powdery building materials, particulate matter, particle size distribution.
\end{abstract}

\section{Introduction}

Particulate matter (PM) in the ambient air has been analyzed in numerous studies for a long period and PM concentrations have been continually monitored for many years. Particle size is one of the most important physical properties of solids which is used in many fields of human activity, such as construction, waste management, metallurgy, fuel fabrication, etc. (Vitez and Travnicek 2010). During recent decades, attention has been focused on fine particles $\left(\mathrm{PM}_{2.5}\right)$ due to their deep penetration into the lungs and the cause of respiratory and circulatory system diseases (Dockery 2009, Pope et al. 2006, Shimada et al. 2011). For example, Laden et al. (2006) had concluded that total, cardiovascular, and lung cancer mortality were each positively associated with ambient $\mathrm{PM}_{2.5}$ concentrations while reduced
$\mathrm{PM}_{2.5}$ concentrations were associated with reduced mortality risk. Thus, the particle size distribution (PSD) (especially aerodynamic one) of potential hazardous particles is a main parameter controlling their behaviour in the air causing possible health effects.

The quantification of PM emissions from industrial processes has been mostly characterized by the PM total emissions. The EMEP/CORINAIR Emission Inventory Guidebook (EMEP, 2007) has already listed pollutant emissions by size segregated $\mathrm{PM}$, including fractions of $\mathrm{PM}_{10}$ and $\mathrm{PM}_{2.5}$. However, not all the processes are listed in these inventories. At the same time, the measurement of size segregated aerosol is not compulsory in industrial inventory measurements according to the Lithuanian air 
pollution legislation. This is only applicable to ambient air pollution measurements, where the standard for $\mathrm{PM}_{10}$ fraction particles (established for protection of human health) for one calendar year is equal to $40 \mu \mathrm{g} / \mathrm{m}^{3}$, and the rate for one day is - 50 $\mu \mathrm{g} / \mathrm{m}^{3}$ (it can not be exceeded more than 35 times per calendar year). The existing limit for $\mathrm{PM}_{2.5}$ fraction is equal to $27 \mu \mathrm{g} / \mathrm{m}^{3}$ in current 2012 year (LR aplinkos, 2010). Thus, there is a missing link between emissions and air quality standardization, and it needs to be filled in.

In order to assess the impacts of stationary sources of pollution to the environment and to simulate pollutant dispersion, it is necessary to determine the PM emissions from stationary pollution sources according to the PSD. One of the ways how to measure the dustiness of the bulk material is described in the European standard (EN 15051:2006). This standard provides details of the design and operation of the continuous drop test method that classifies the dustiness of solid bulk material in terms of health-related fractions.

Particulate matter aerosol can be produced during the extraction of many construction materials, various industrial processes as well as on a building site. According to Berge (2009) polluting particles may also be a problem during a demolition phase. The so-called material pollution, due to construction activities, consists of dust (PM) emissions from various powder building materials that are exposed to physical or chemical activities.

The construction aerosol was an object of numerous studies worldwide. Muleski et al. (2005) in their paper had summarized the results of a multi-year research program undertaken by the EPA's National Risk Management Research Laboratory (NRMRL) to assess PM emissions from construction activities. Several studies dealt with the assessment of PSD and emission factors from various industrial plants e.g. cement production (Ehrlich et al. 2007, Canpolat et al. 2002). Ehrlich et al. determined the PSD of fine dust $\left(\mathrm{PM}_{10}, \mathrm{PM}_{2.5}\right.$ and $\left.\mathrm{PM}_{1}\right)$ in the waste gases from various industrial plants using eight- or six- stage cascade impactors (Anderson and Stroehlein impactors) in several regions of Germany. This study has shown that a cascade impactor working under similar sampling conditions is a suitable technique for determining PSD of various dust, only the selection of the sampling period should be taken into account trying to avoid overloading of the impactor stages.

In the ambient air study by Santacatalina et al. (2010) in Southeast Spain excessive levels of $\mathrm{PM}_{10}$ and $\mathrm{PM}_{2.5}$ were registered in 2006 and 2007, which could be attributed to specific sources, mainly from large public construction work (highway construction), cement and ceramic manufacturing. It was observed that the main sources influencing an ambient $\mathrm{PM}_{10}$ fraction are from mineral sources and these pollution episodes were attributable to the public construction work. Recently, potential hazard of building materials (typically from concrete, cement, wood, stone, and silica) to human health related to the release of particulate matter was described in the wide press by Gray, 2010.

This study aimed to determine PSD of powdery building material aerosol and as an ambient air pollutant. The obtained data were applied to calculating size-segregated emission factors. The results may be utilized to assess potential pollution levels and PSD of fine dust $\left(\mathrm{PM}_{10}\right.$ and $\left.\mathrm{PM}_{2.5}\right)$ in either ambient or indoor air during various processes of construction or buildings renovation.

\section{Methodology}

Eleven building materials were chosen for determination of particle size distribution (in alphabetic order): 1) cement; 2) chalk; 3) clay; 4) gypsum; 5) hydrated lime; 6) masonry grout; 7) quartz sand; 8) sand; 9) structural lime; 10) wood grinding dust and 11) wood sawdust. Building materials used in laboratory studies were selected in accordance to in reality used building materials to ensure uniform particle size distribution as possible, their shape, composition, and other important properties (Kaya et al. 1996).

PSD of various powdery building materials were assessed by two aerosol generation methods: fluidization (dust is resuspended by direct entrainment into airflow in a metal tube) and gravitation (a source sample fell as a discrete slug through the air into an enclosed chamber from which dust is evacuated). These two methods represent actual industrial activities, such as pneumo-transportation and unloading, and are easily modelled in laboratory conditions (Gill et al., 2006).

In a case of fluidization (Fig. 1.), $0.1 \mathrm{~g}$ of powdery building material was inserted into an injection tube. The material sample was dispersed into the experimental chamber by a short gust of compressed air. The air was withdrawn from the chamber via sampling tubes together with sampled particles. In a case of gravitation (Fig. 2.), $1.0 \mathrm{~g}$ of powdery building material was dropped from $40 \mathrm{~cm}$ height into an enclosed chamber from which dust was evacuated. In both cases, particle size distribution was determined by an Aerodynamic particle sizer (APS) (model 3321, TSI Incorporated, USA) and an optical particle counter (OPC) (model 3016, Lighthouse worldwide solutions, Fremont CA 94538, USA). Additionally, the PSD based on mass concentrations was determined using a three-stage cascade impactor ( $\mathrm{PM}_{10}$ Impactor, Dekati Ltd., Finland). PM samples were collected on aluminium foil plates whose surfaces were covered with a thin layer of vacuum silicon paste (Dow Corning 732, Dow Corning Corp., USA) to prevent the particle bounce-off. Before starting a new measurement, the inner surface of the chamber was covered with fresh aluminium foil and replaced during each new measurement. 
The measurement range of APS was from 0.5 to $20 \mu \mathrm{m}$ in 56 size channels, with the sampling flow rate of $1 \mathrm{l} / \mathrm{min}$. The OPC measured particle concentration in 6 channels: $0.3-0.5 \mu \mathrm{m} ; 0.5-1 \mu \mathrm{m}$; $1-2.5 \mu \mathrm{m} ; 2.5-5 \mu \mathrm{m} ; 5-10 \mu \mathrm{m} ;>10 \mu \mathrm{m}$, with the flow rate of 2.88 litres per minute. During impactor measurements, the particles were collected in the fractions of $>10 \mu \mathrm{m} ; 10-2.5 \mu \mathrm{m} ; 2.5-1 \mu \mathrm{m} ;<1 \mu \mathrm{m}$, with the flow rate of $10 \mathrm{l} / \mathrm{min}$. A three stage cascade impactor is confirmed to be suitable for investigation of powdery building materials, if the total particle mass concentration does not exceed the allowable limit value of $40 \mathrm{mg} / \mathrm{m}^{3}$ as half-hourly averages under standard conditions (273 K, $1013 \mathrm{hPa}$, dry gas) (ISO $232102009)$.

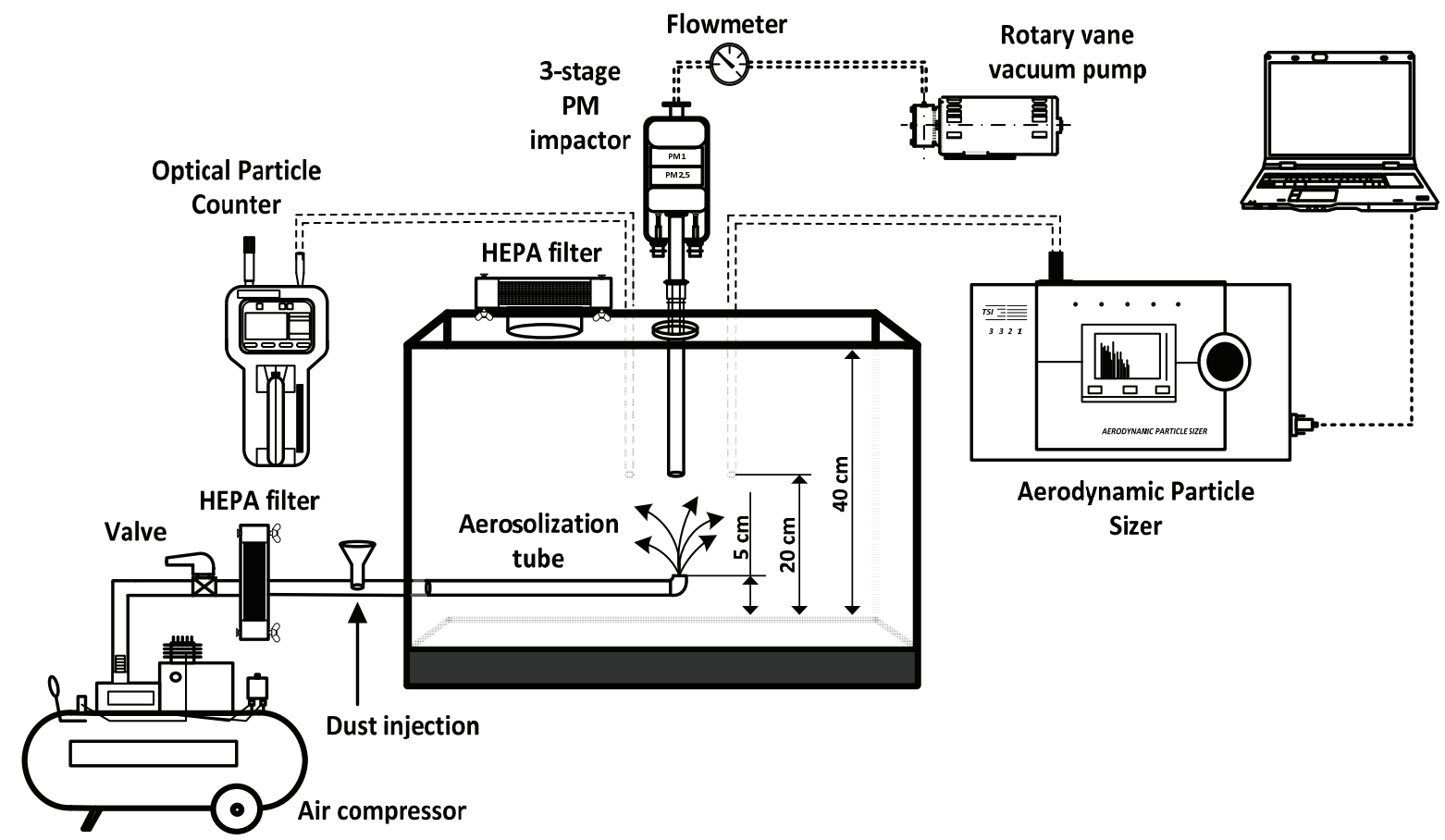

Fig. 1. Experimental system for simulating aerosolization of powdery building materials by fluidization

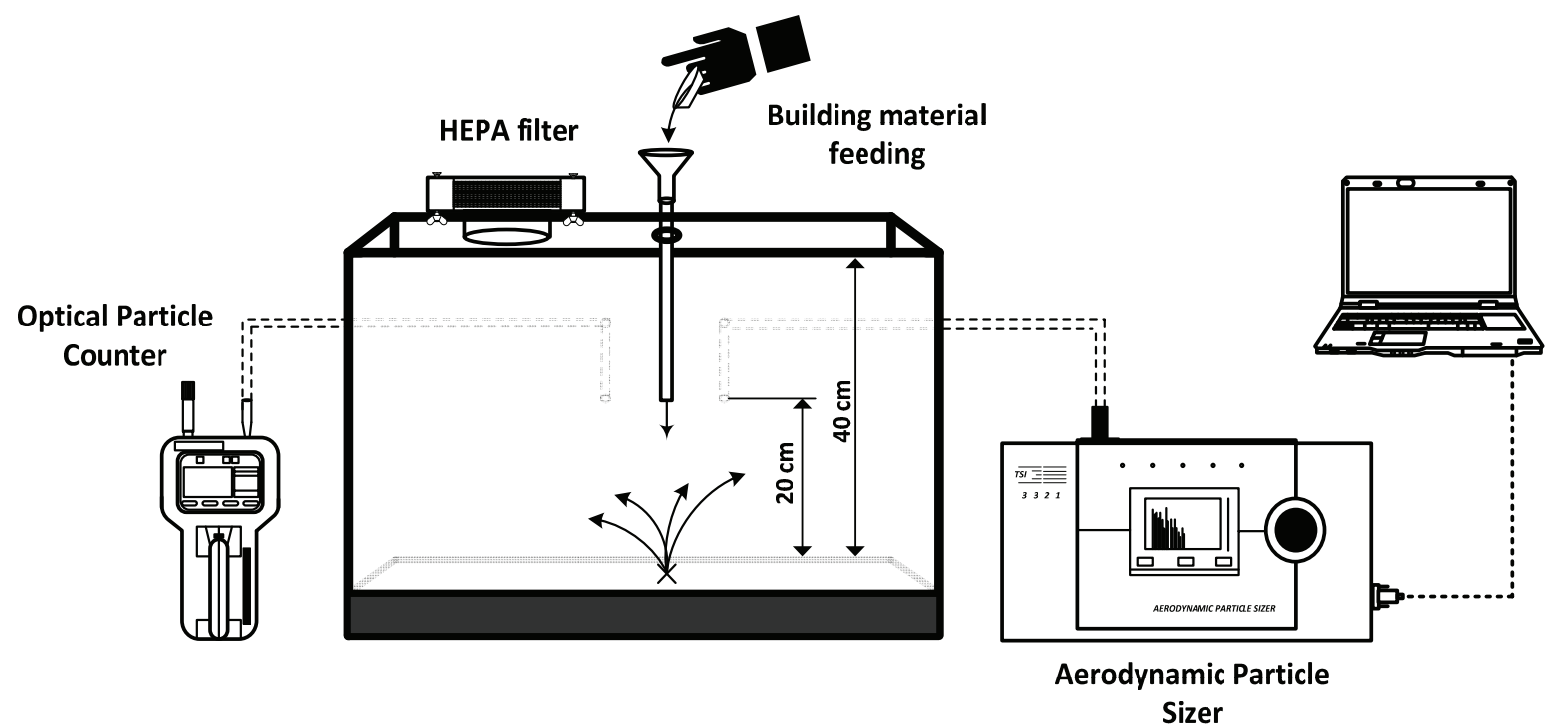

Fig. 2. Experimental system for simulating aerosolization of powdery building materials by gravitation

Aerosol was sampled by separate tubes at the same height $(20 \mathrm{~cm}$ from the chamber bottom), tubes from APS and OPC were inserted into different sides of the chamber. The supplied air for particle resuspension was cleaned using a high efficiency particulate filter (HEPA, class 12). The air was withdrawn from the chamber via sampling tubes together with sampled particles.

Aluminium substrates were weighted twice before and after sampling by a microbalance with sensitivity of $\pm 1 \mu \mathrm{g}$ (model MX5, Radwag, Poland). The substrates were equilibrated in a thermostat at the room temperature at relative humidity of $40-50 \%$ for 
24-h. Laboratory blanks were collected and analyzed for $\mathrm{PM}_{10}$ and $\mathrm{PM}_{2.5}$ to reduce gravimetric bias due to filter handling during and/or after sampling. From the weight differences and airflow rate $\mathrm{PM}_{10}$ and $\mathrm{PM}_{2.5}$ concentrations $\left(\mu \mathrm{g} / \mathrm{m}^{3}\right)$ were determined.

\section{Results and Discussion}

The PSD of resuspended particulate matter from powdery building materials was rather similar obtained either by fluidization or gravitation methods, with an exception of wood sawdust and sand, which varied substantially compared to other materials. In a case of fluidization, wood grinding dust produced most particles in a coarse range (mode equal to 3.28 $\mu \mathrm{m})$, while gypsum particles were dispersed in a finer range $(1.98 \mu \mathrm{m}$, Table 1$)$. In a case of gravitation the highest mode was also assessed for wood grinding dust - $3.52 \mu \mathrm{m}$ and the lowest - for wood sawdust $0.54 \mu \mathrm{m}$

Table 1. Value of modes based on number $(N)$ and mass (M) concentration of building materials

\begin{tabular}{|l|c|c|c|c||}
\hline \multirow{3}{*}{ Building material } & \multicolumn{2}{|c|}{ Fluidization } & \multicolumn{2}{c|}{ Gravitation } \\
\cline { 2 - 5 } & \multicolumn{2}{|c|}{ Mode, $\mu \mathrm{m}$} & \multicolumn{2}{c|}{ Mode, $\mu \mathrm{m}$} \\
\cline { 2 - 5 } & $\mathbf{N}$ & $\mathbf{M}$ & $\mathbf{N}$ & $\mathbf{M}$ \\
\hline Cement & 2.29 & 3.28 & 2.64 & 3.52 \\
\hline Chalk & 2.29 & 3.05 & 2.64 & 13.82 \\
\hline Clay (granulated) & 2.64 & 3.52 & 3.05 & 4.07 \\
\hline Gypsum & 1.98 & 2.84 & 2.29 & 3.05 \\
\hline Hydrated lime & 2.29 & 4.37 & 3.05 & 4.70 \\
\hline Masonry grout & 2.46 & 3.52 & 3.28 & 4.37 \\
\hline Quartz sand & 2.64 & 4.37 & 2.64 & 3.79 \\
\hline Sand & 2.29 & 15.96 & 3.28 & 4.70 \\
\hline Structural lime & 2.13 & 4.37 & 2.64 & 5.05 \\
\hline Wood grinding dust & 3.28 & 5.05 & 3.52 & 5.83 \\
\hline Wood sawdust & 2.64 & 19.81 & 0.54 & 19.81 \\
\hline
\end{tabular}

With respect to mass concentration (M), the highest modes by a fluidization method were determined $19.81 \mu \mathrm{m}$ and $15.96 \mu \mathrm{m}$ for wood sawdust and sand, respectively. The lowest mode was determined for gypsum - $2.84 \mu \mathrm{m}$. In a case of gravitation, the highest modes were assessed for wood sawdust $19.81 \mu \mathrm{m}$ and chalk $13.82 \mu \mathrm{m}$, and the lowest one for gypsum $-3.05 \mu \mathrm{m}$. It is clearly visible that PSD by mass concentration retains relatively uniform data during both methods, only chalk and sand have revealed significant different modes.

Comparative analysis of the highest aerosol modes generated by fluidization and gravitation methods revealed a general trend that slightly higher modes of number $(\mathrm{N})$ and mass $(\mathrm{M})$ concentrations were observed for aerosols generated by a gravitation method.
Comparison of PSD (N) of several powder building materials (cement, chalk, gypsum, sand and wood sawdust) during fluidization and gravitation are presented in Fig. 3. It has appeared that both techniques produce slightly different particle size distributions based on the number concentration.

During fluidization and gravitation bimodal particle size distributions were observed mostly by OPC, only during gravitation APS has revealed more tendencies towards the clear bi-modal size distribution (chalk - 0.63 and $2.64 \mu \mathrm{m}$, sand -0.54 and $2.29 \mu \mathrm{m}$, wood sawdust -0.54 and $3.52 \mu \mathrm{m}$ ). PSD measured by the APS was slightly shifted compared to OPC in all measurements. The differences were caused by different measuring ranges and resolutions of the instruments (OPC starts to measure from $0.3 \mu \mathrm{m}$, APS from $0.5 \mu \mathrm{m}$ ), and possibly due to different classification techniques of particles (optical vs. aerodynamic/optical).

In some cases of PSD by OPC (cement and wood sawdust), mostly from fluidization, the modes were visible at $>10 \mu \mathrm{m}$ channel (increase of PM). This could be caused due to high PM concentration in the chamber approaching an upper range of the instrument operation that brings discrepancies in measurement results, e.g., two $5 \mu \mathrm{m}$ particles passing throughout the laser beam of an instrument could be identified as a one 10 micrometer particle. Therefore, this method is not always accurate for such experiments when PM concentrations approach an upper range of the instrument. In such cases a PM impactor which classifies particles aerodynamically may be utilized.

In comparison to other studies, such as Ehrlich et al. 2007, during our study the majority of analyzed building materials emitted rather similar concentrations of $\mathrm{PM}_{10}$ but with different portions of $\mathrm{PM}_{10}$ of the TPM emission. The $\mathrm{PM}_{10}$ emissions from industrial plants in Germany amounted to more than $90 \%$ and the $\mathrm{PM}_{2.5}$ portion between $50 \%$ and $90 \%$ of the $\mathrm{PM}_{\text {total }}$ emission. In our study the $\mathrm{PM}_{10}$ portion (as determined by 3-stage impactor measurements) amounted between $29.5 \%$ and $86.6 \%$ (quartz sand and masonry grout, respectively) the $\mathrm{PM}_{2.5}$ portion between $6.6 \%$ and $28.1 \%$ (quartz sand and clay, respectively) of the $\mathrm{PM}_{\text {total }}$ emissions. The $\mathrm{PM}_{1.0}$ portion constituted between $0.3 \%$ and $6.5 \%$ (chalk and clay, respectively) of the $\mathrm{PM}_{\text {total }}$ emission (Table 2). $\mathrm{PM}_{10}$ fraction mostly composed a significant part of all particles of aerosol ( 70-75 \%) with an exception of quartz sand and wood dust which revealed the lowest $\mathrm{PM}_{10}, \mathrm{PM}_{2.5}$ and $\mathrm{PM}_{1}$ ratios compared to $\mathrm{PM}_{\text {total }}$. At the same time, $\mathrm{PM}_{2.5}$ fraction represents a relatively small proportion of total aerosolized PM ( 15-20\%). On the other hand, this finding shows that although the tested methods generate a substantial amount of fine aerosol fraction, but if inhaled, it may travel to the deepest pathways of a respiratory system and cause associated health effects. 

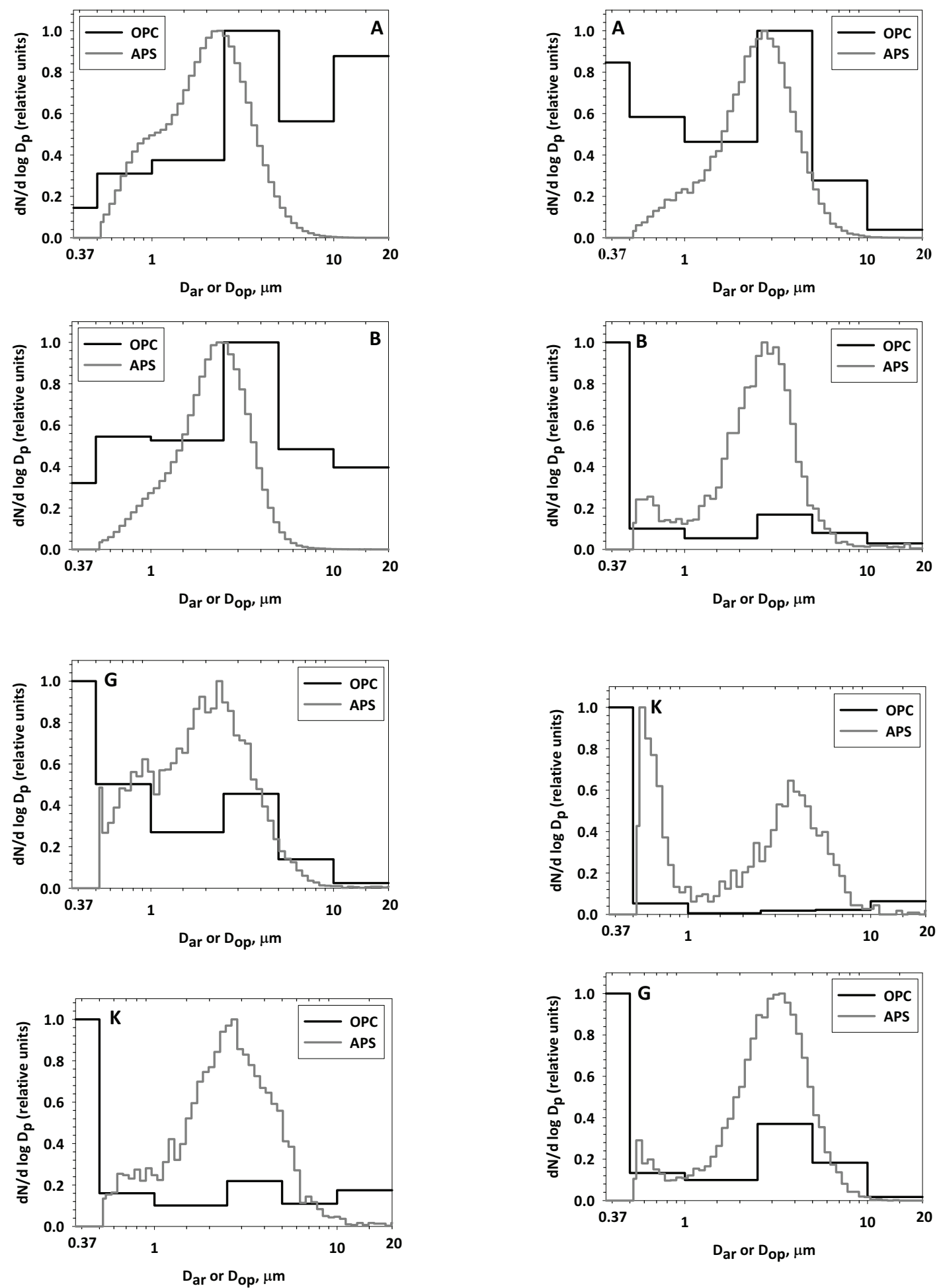

Fig. 3. Particle size distribution (dN) of a) cement, b) chalk, d) gypsum, g) sand, k) wood sawdust, during fluidization and particle size distribution (dN) of a) cement, b) chalk, d) gypsum, g) sand, $k$ ) wood sawdust, during gravitation by $A P S$ 
The methods utilized in the above presented experiments for the particle aerosol generation are laboratory based. They are created to mimic closely the process of a scaled-down industrial pollution event. It may be expected that the industrially produced aerosol will have a similar PSD, if the same type of material is used and no pollution control devices are installed between aerosol generation and sampling sites. Of course, the mass and number of generated particles will depend on the mass flow of material. i.e., the emission factors expressed as $\mathrm{g} / \mathrm{s}$ will be substantially higher compared to laboratory conditions.

Table 2. Fractional composition of particulate matter aerosol (by mass concentration, in \% of $P M_{\text {total }}$ )

\begin{tabular}{|l|c|c|c||}
\hline \multicolumn{1}{|c|}{ Building material } & $\mathbf{P M}_{\mathbf{1}}$ & $\mathbf{P M}_{\mathbf{2 . 5}}$ & $\mathbf{P M}_{\mathbf{1 0}}$ \\
\hline Cement & 1.3 & 13.3 & 76.6 \\
\hline Chalk & 0.3 & 12.1 & 78.7 \\
\hline Clay (granulated) & 6.5 & 28.1 & 51.1 \\
\hline Gypsum & 1.6 & 16.1 & 81.1 \\
\hline Hydrated lime & 0.6 & 11.6 & 79.6 \\
\hline Masonry grout & 0.4 & 13.2 & 86.6 \\
\hline Quartz sand & 0.5 & 6.6 & 29.5 \\
\hline Sand & 2.8 & 22.7 & 49.8 \\
\hline Structural lime & 1.3 & 11.7 & 75.7 \\
\hline Wood grinding dust & 1.4 & 9.9 & 35.7 \\
\hline Wood sawdust & 1.0 & 8.8 & 38.3 \\
\hline \hline
\end{tabular}

\section{Conclusions}

This study has presented the particle size distributions for 11 powdery building materials widely used in construction or renovation of buildings (cement, chalk, clay, wood sawdust, wood grinding sawdust, gypsum, hydrated lime, masonry grout, quartz sand, sand and structural lime). Results have revealed that gravitational generation of particles produce a slightly higher mode of number and mass concentrations in comparison to aerosol generated by fluidization. The particle size distributions produced by an optical particle counter and aerodynamic particle sizer are of slightly different shape due to different measurement techniques and ranges.

In our study the $\mathrm{PM}_{10}$ fraction amounted between $30 \%$ and $87 \%$ and the $\mathrm{PM}_{2.5}$ portion between $7 \%$ and $28 \%$ of the total particulate matter emission. The $\mathrm{PM}_{1.0}$ portion constituted between $3 \%$ and $7 \%$ of the total PM emission. The highest ratio was calculated for masonry grout $\mathrm{PM}_{10} / \mathrm{PM}_{\text {total }} 0.87$, the lowest ratio of quartz sand for $\mathrm{PM}_{10} / \mathrm{PM}_{\text {total }} 0.30$. The highest ratio $\mathrm{PM}_{2.5} / \mathrm{PM}_{\text {total }}$ was calculated for clay 0.28 , the lowest ratio $\mathrm{PM}_{2.5} / \mathrm{PM}_{\text {total }}$ for quartz sand 0.07 .

The results of this study imply that the examined powder being mainly produced by mechanical processes, substantial quantities of fine PM (in the
$\mathrm{PM}_{25}$ range) are emitted into the ambient air during their application processes and may be of potential threat to human health in construction or structural renovation of buildings.

\section{Acknowledgement}

The authors acknowledge Dr. Axel Zerrath and Sr. Maksim Kireitseu of TSI GmbH for their valuable comments on data interpretation.

\section{References}

BERGE B. 2009. The ecology of building material. Second edition. pp. 1-421. ISBN: 978-1-85617-537-1. http://dx.doi.org/10.1016/B978-1-85617-537-1.00001-9

CANPOLAT B.R., ATIMTAY A.T., MUNLAFALIOGLU I., KALAFATOGLU E., EKINCI E. Emission factors of cement industry in Turkey. TUBITAKMarmara Research Center, Water, Air and Soil Pollution, 2002, Vol. 138. pp 235-252. Turkey. http://dx.doi.org/10.1023/A:1015502131180

DOCKERY D.W. Health effects of particulate air pollution. Annals of Epidemiology, 2009, Vol. 19, pp. 257-263.

http://dx.doi.org/10.1016/j.annepidem.2009.01.018

USA.

EHRLICH C., NOLL G., KALKOFF D.W., BAUMBACH G., DREISEIDLER A. PM10, PM2.5 and PM1.0 Emissions from industrial plants. Results from measurement programmes in Germany. Atmospheric Environment 2007, Vol. 41. pp. 6236-6254. Germany. http://dx.doi.org/10.1016/j.atmosenv.2007.03.059

EMEP/CORINAIR Emission Inventory Guidebook 2007. EEA Technical report No 16/2007. European Environment Agency.

GILL T.E., ZOBECK T.M., STOUT J.E. Technologies for laboratory generation of dust from geological materials. Journal of Hazardous Materials. Journal of Hazardous Materials, 2006, Vol. 132. pp. 1-13. United States of America. http://dx.doi.org/10.1016/j.jhazmat.2005.11.083

GRAY J. Sustainable Build, Pollution from Construction, 2010. http://www.sustainablebuild.co.uk/PollutionFromConstructi on.html

ISO 23210, 2009. Stationary source emissions Determination of $\mathrm{PM}_{10} / \mathrm{PM}_{2.5}$ mass concentration in flue gas - Measurement at low concentration by use of impactors. Published in Switzerland.

KAYA E., HOGG R., MUTMANSKY J.M. Evaluation of procedures for production of dust samples for biomedical research, Applied Occupational and Environmental Hygiene, Vol. 11, pp. 745-750, 1996. United States of America. http://dx.doi.org/10.1080/1047322X.1996.10389964 
LADEN F., SCHWARTZ J., SPEIZER F.E., DOCKERY D.W. Reduction in fine particulate air pollution and mortality-extended follow-up of the Harvard six cities study. American Journal of Respiratory and Critical Care Medicine, 2006, Vol. 173, pp. 667-672. http://dx.doi.org/10.1164/rccm.200503-443OC

LR aplinkos ministro ir LR sveikatos apsaugos ministro $2001 \mathrm{~m}$ įsakymo nr. 591/640 „Dèl aplinkos oro užterštumo normų nustatymo" pakeitimo, 2010. Vilnius, Lietuva.

LST EN 15051:2006. Workplace exposure Measurement of the dustiness of bulk material - Part 3: Continuous drop method.

MULESKI G.E., COWHERD C. Jr., KINSEY J.S. Particulate Emissions from Construction Activities. Journal of the Air and Waste Management Association, 2005, Vol. 55. pp. 772-783.

POPE C.A.III, DOCKERY, D.W. Health effects of fine particulate air pollution: lines that connect. Journal of the Air and Waste Management Association, 2006, Vol. 56, pp. 709-742. United States of America. http://dx.doi.org/10.1080/10473289.2006.10464485

SANTACATALINA M., RECHE C., MINGUILLON M.C., ESCRIG A., SANFELIX V., CARRATALA A., NICOLAS J.F., YUBERO E., CRESPO J., ALASTUEY A., MONFORT E., MIRO J.V., QUEROL X. Impact of fugitive emissions in ambient PM levels and composition: A case study in Southeast Spain. Science of the Environment, 2010, Vol. 408. pp. 4999-5009. Spain.

SHIMADA Y., MATSUOKA Y. Analysis of indoor PM2.5 exposure in Asian countries using time use survey. Science of the Total Environment, 2011, Vol. 409. pp. 5243-5252. Japan. http://dx.doi.org/10.1016/j.scitotenv.2011.08.041

VITEZ T., TRAVNICEK P. Particle size distribution of sawdust and wood shaving mixture. Department of Agriculture, Food and Environmental Engineering, 2010, Vol. 56, No 4. pp. 154-158. Czech Republic.
MSc. Tadas Prasauskas - PhD student at the Department of Environmental Engineering, Kaunas University of Technology, Kaunas, Lithuania.

Main research area: Effects of construction and renovation processes to the ambient air quality.

Address: KTU, Faculty of Chemical Technology. Radvilènų pl. 19, LT50254, Kaunas

Tel.: +370-37-351008

E-mail: tadpras@ktu.lt

BSc. Aida Žemaitytė - Department of Environmental Engineering, Kaunas University of Technology, Kaunas, Lithuania.

Main research area: PM pollution from powdery materials.

Address: KTU, Faculty of Chemical Technology. Radvilènų pl. 19, LT50254, Kaunas

Tel.: +370-37-351008

E-mail: aidzema@gmail.com

MSc. Edvinas Krugly - PhD student at the Department of Environmental Engineering, Kaunas University of Technology, Kaunas, Lithuania.

Main research area: Environmental chemistry, fate of polycyclic organic pollutants in environment.

Address: KTU, Faculty of Chemical Technology. Radvilènų pl. 19, LT50254, Kaunas

Tel.: +370-37-351008

E-mail: edvkrug@ktu.lt

MSc. Darius Čiužas - researcher at Department of Environmental Engineering, Kaunas University of Technology, Kaunas, Lithuania.

Main research area: Indoor air quality measurements.

Address: KTU, Faculty of Chemical Technology. Radvilènų pl. 19, LT50254, Kaunas

Tel.: +370-37-351008

E-mail: darius.ciuzas@stud.ktu.lt

Assoc. Prof. Dr. Dainius Martuzevičius - head of the Department of Environmental Engineering, Kaunas University of Technology, Kaunas, Lithuania.

Main research area: Ambient and indoor air quality.

Address: KTU, Faculty of Chemical Technology. Radvilènų pl. 19, LT50254, Kaunas

Tel.: +370-37-351008

E-mail: daimart@ktu.lt 


\title{
Birių statybiniụ medžiagų aerozolio dalelių dispersinès sudèties apibūdinimas fluidizacijos ir gravitacijos metodais
}

\author{
Tadas Prasauskas, Aida Žemaitytė, Edvinas Krugly, Darius Čiužas, \\ Dainius Martuzevičius \\ Aplinkos inžinerijos katedra, Kauno technologijos universitetas, Lietuva
}

(gauta 2012 m. balandžio mèn., priimta spaudai $2012 m$. rugsèjo mèn.)

Šioje studijoje siekiama nustatyti dažniausiai naudojamų birių statybinių medžiagų (cemento, kreidos, molio, medžio pjuvenų, medienos šlifavimo dulkių, gipso, gesintų kalkių, mūro skiedinio, kvarcinio smèlio, smèlio ir struktūrinių kalkių) aerozolio dalelių pasiskirstymą pagal dydị taikant du aerozolizacinius metodus: fluidizacijos ir gravitacijos. Fluidizacijos ir gravitacijos metodai simbolizuoja realias statybos pramonès veiklas, pavyzdžiui, pneumotransportavimas ir iškrovimas. Abu dalelių aerozolizacijos mechanizmai buvo modeliuojami laboratorinèmis sąlygomis.

Aerozolizuotų kietujų dalelių pasiskirstymas pagal dydị iš birių statybinių medžiagų buvo panašus taikant tiek fluidizacijos, tiek ir gravitacijos metodus, išskyrus medienos pjuvenas ir smèlį. KD10 frakcija sudarè nuo 30 proc. ir 87 proc. bendros KD frakcijos masės dalies, KD2,5 - nuo 7 proc. iki 28 proc. bendros KD frakcijos masės dalies, o KD1 - nuo 3 proc. iki 7 proc. bendros KD frakcijos masės dalies. Didžiausias KD10/KDBendras santykis buvo apskaičiuotas mūro skiediniui - 0,87, o mažiausias kvarciniam smèliui - 0,30. Didžiausias KD2,5/KDBendras santykis buvo apskaičiuotas smėliui - 0,23, o mažiausias kvarciniam smėliui - 0,07. Nustatytas didelis KD2,5 frakcijos dalelių išsiskyrimas rodo, kad birios statybinès medžiagos gali būti pavojingos žmonių sveikatai. 